${ }^{\circ}$ Copyright by Pusat Riset dan Pengembangan Produk Halal Universitas Airlangga | e-ISSN: 2654-9778

\title{
VALIDATION GAS CHROMATOGRAPHY-FID METHOD FOR ANALYSIS OF ETHANOL CONTENT IN VINEGAR
}

\author{
METODE VALIDASI GAS CHROMATOGRAPHY-FID UNTUK ANALISIS KONTEN ETHANOL \\ PADA CUKA \\ Indah Noviyanti Ruhmana Pulungan, Sugijanto Kartosentono, Amirudin Prawita \\ Fakultas Farmasi, Universitas Airlangga \\ JI. Dharmawangsa Dalam Surabaya 60286, Indonesia \\ Fakultas Farmasi Universitas Airlangga,Jl.Dharmawangsa Dalam, Surabaya 60286, Indonesia \\ *Email : sugijanto@ff.unair.ac.id
}

\begin{abstract}
ABSTRAK
Proses produksi cuka dapat disintesis oleh kimia atau mikrobiologi. Ajaran Islam menjelaskan bahwa cuka tidak boleh dikonsumsi jika mengandung etanol $\geq 1 \%$, karena dikategorikan ke dalam khamr. Konsentrasi maksimum fermentasi cuka adalah 1,0\%. Penelitian ini bertujuan untuk menganalisis kandungan alkohol yang terdiri dari cuka. Metode validasi yang digunakan dalam penelitian ini adalah: selektivitas, linearitas, jarak, presisi, akurasi, LOD dan LOQ. Instrumen analisisnya adalah kromatografi gas Agilent 6890 Series GC System, dengan Flame Ionization Detector (FID) dan kolom HP-5 (5\% Phenyl 95\% Methyl Siloxane), dan kondisi optimal diperoleh dengan menggunakan suhu inlet dan detektor $250^{\circ} \mathrm{C}$ sementara suhu oven diprogram awalnya pada $40^{\circ} \mathrm{C}$, tahan selama 5 menit, dan dinaikkan menjadi $5^{\circ} \mathrm{C} /$ menit sampai $200^{\circ} \mathrm{C}$ digunakan dalam penelitian ini. Untuk rasio split dicapai pada 50:1 dan volume injeksi adalah 1,0 1 . Metode ini terbukti selektif dan menunjukkan linearitas, presisi dan akurasi dengan $r=0,9995 ; 5,63 \%$ dan 101,25\%, masing-masing. Di sisi lain, metode terbukti bahwa sampel mengandung alkohol. Akhirnya, hasil analisis kadar etanol kuantitatif dalam cuka dari Arab Saudi adalah 2,28,10-2\% v / v; dan merek cuka " $x$ " dari pasar di Surabaya adalah 1,17.10-2 v/v.

Kata kunci: Cuka, etanol, kromatografi gas, metode validasi
\end{abstract}

\begin{abstract}
Production process of vinegar could be synthesized by chemical or microbiological. In Islam, vinegar must not be consumed if contains ethanol $\geq 1 \%$, because it is categorized into khamr. The maximum concentration of vinegar fermentation is $1,0 \%$. This research was to analyze the alcohol compund that consist in vinegar. The validation method that used in this study are: selectivity, linearity, range, precision, accuracy, LOD and LOQ. The analysis instrument was gas chromatography Agilent 6890 Series GC System, with a Flame Ionization Detector (FID) and a column HP-5 (5\% Phenyl 95\% Methyl Siloxane), and optimal conditions were obtained by using temperature of inlet and detector of $250^{\circ} \mathrm{C}$ whilst the temperature of oven programed initially at $40^{\circ} \mathrm{C}$, hold for 5 minutes, and raised to $5^{\circ} \mathrm{C} / \mathrm{min}$ to $200^{\circ} \mathrm{C}$. were used in this study. For split ratio was achieved at 50:1 and the injection volume was $1.0 \mu$. The methods were proven selective and demonstrated linearity, precision and accuracy with $r=0.9995 ; 5,63 \%$ and $101,25 \%$, respectively. On the other hand, the methods were proven that the sample contains alcohol. Finally, the result of quantitative ethanol contents analysis in vinegar from Saudi Arabia is $2,28.10^{-2} \% \mathrm{v} / \mathrm{v}$; and vinegar brand " $\mathrm{x}$ " from market in Surabaya is $1,17.10^{-2} \mathrm{v} / \mathrm{v}$.
\end{abstract}

Keyword: Vinegar, ethanol, gas chromatography, validation method 


\section{INTRODUCTION}

Vinegar acid has been known to humans about 10,000 years ago and the vinegar used as a food flavor has been commercially produced about 5000 years ago (Tan, 2005; Johnston and Gass, 2006). Traditional vinegar is produced from raw materials containing sugar or starch in two stages of fermentation. First stage is producing ethanol and the next step is to produce acetic acid.

Acetic acid or more commonly known as vinegar $\left(\mathrm{CH}_{3} \mathrm{COOH}\right)$ is a clear colorless liquid, a distinctive pungent smell, and has a sharp sour taste. Acetic acid can be mixed with water, with ethanol, and with glycerol (Anonymous, 2014). The process of producing acetic acid can be carried out chemically as well as microbiologically. The chemical process of acetic acid production widely used in industry is the oxidation of n-butane to form acetic acid or vinegar (Ibrahim, 2011). For food needs, the production of acetic acid is done through microbiological process, one of which is fermentation of raw materials containing sugar or starch. Fermentation is performed by using bacteria from the genus Acetobacter under aerobic condition. One of the most widely used species for acetic acid fermentation is Acetobacter aceti (Tjahjono, 2007). The process of making vinegar through the process of fermentation from carbohydrates to ethanol, then continues to be acetic acid or vinegar. From the process of making vinegar, it is seen that in vinegar is still contained ethanol.

Ethanol has pharmacological properties when it enters the stomach into absorption, and into the bloodstream is carried to the heart and transmitted to the brain and works as a central nervous (suppressor) depressant. The strength of this pressing action is heavily dependent on the level of ethanol in the blood; while the ethanol content in the blood is influenced by the amount of drunk ethanol. Ethanol in the blood has toxicity in the form of: nausea, vomiting, depression or central nervous system stimulation, dizziness, loss of coordination, causing dilation of blood vessels, produce heat, can even cause death (Gilman et al., 2011).

Related to that ethanol requires special supervision, supervision by means of restrictions in circulation. Supervision related to the quality of vinegar acids in circulation, closely related to the control of ethanol, because in the fermentation process not all ethanol turned into vinegar, so most likely vinegar still contains ethanol. The Government of the Republic of Indonesia in the Regulation of the Minister of Health $86 /$ Men.Kes/Per/IV/77 on Liquor provides policy about drinks containing ethanol $\geq 1 \%$ including alcoholic beverages (Ditjen POM, 1994).

Related with alcohol as well as the Government of the Republic of Indonesia in Regulation of the Minister of Trade no. 20/M-DAG/PER/4/2014 concerning Control and Supervision on Procurement, Distribution and Sales of Alcoholic Beverages provides a policy that drinks containing ethanol with $\geq 1 \%$ are liquor / alcoholic beverages. For the supervision of alcohol in vinegar acid according to SNI 01-43711996 on the fermentation vinegar required that the remaining alcohol of fermented vinegar is a maximum of $1 \%$.

The permitted vinegar should be reviewed from its ingredients; if the ingredients come from coconut palm, apple, sugar, malt, then permission can be assured as long as it does not exceed the range of certain alcohol content. In each country has different provisions what percentage of the maximum amount of alcohol in the food. Malaysia through JAKIM's fatwa establishes maximum levels of alcohol in food is $0,01 \%$; Thailand through AOl's fatwa establishes maximum levels of alcohol in food is $1.0 \%$; Singapore through the MUIS' fatwa set the maximum level of ethanol in food is $0,5 \%$; Brunei through BIRC's fatwa set maximum rate is $0,0 \%$; Europe establishes maximum levels of ethanol in food is less than $0,5 \%$; while Indonesia through the fatwa (MUI) determined that the maximum amount of alcohol in food is $1,0 \%$, but vinegar made from khomar or the liquor industry still should not be used (Hisham, 2011).

Ethanol in vinegar creates its own problems in the Islamic society, so it needs to be examined in view of the provisions of the MUl's fatwa that the maximum amount of alcohol in food should not be more than $1 \%$; therefore how much alcohol in vinegar needs to be analyzed.

Determination of ethanol content can generally be done by volumetric method, spectrophotometry, and gas chromatography (Latimer, 2012). Gas chromatography is the most widely used method for the analysis of volatile compounds, so it is widely applied to the determination of ethanol content in various samples. Gas chromatography has the advantage of relatively fast analysis time, has a high sensitivity (Sun et al., 2012). There are several detectors that can be used for gas chromatographic instruments, such as DIN (Flame Ionisation Detector), DHP (Heat Hose Detector), DNF (Nitrogen-Phosphere Detector), DTE (Electron Capture Detector), and SM (Mass Spectrometer). FID or flame ionization

\footnotetext{
${ }^{\circ}$ Copyright by Pusat Riset dan Pengembangan Produk Halal Universitas Airlangga | e-ISSN: 2654-9778
} 
detector is most widely used. This detector is sensitive to compounds containing $\mathrm{C}-\mathrm{H}$ bonds. $\mathrm{H}_{2} \mathrm{O}$ or $\mathrm{CO}_{2}$ gas does not respond to FID, whereas halogens and amines give a weak response (Skoog, 2007).

To know the presence and absence of ethanol and how much level in vinegar can be analyzed by using gas chromatography-DIN. Qualitative analysis of chemical content is performed to determine whether there is ethanol in vinegar samples. When the ethanol compound is detected, then the research is continued for the determination of ethanol content. In this research, the validation of gas chromatography method which includes LOD, LOQ, selectivity test, linearity, accuracy and precision to obtain valid method and can give optimal result (Yuwono and Indrayanto, 2005). For research used one of the vinegar products circulating in Saudi Arabia (Mecca) and in Indonesia (Surabaya).

\section{MATERIALS AND METHODS}

\section{Tools}

The tools used in the study include Vortex Mixers type gas chromatography Agilent 6890 Flame Ionization Detector (FID), temperature $250^{\circ} \mathrm{C}$, HP-5 capillary column ( $5 \%$ Phenyl $95 \%$ Methyl Siloxane/) Length $30,0 \mathrm{~m}$, diameter $0,32 \mathrm{~mm}, 0,25 \mu \mathrm{m}$ film table, gas carrier Helium at a velocity of 0,5 $\mathrm{ml} / \mathrm{min}$, a $250^{\circ} \mathrm{C}$ inlet temperature, a $1: 50$ split ratio, an oven temperature of $40^{\circ} \mathrm{C}$ for $5 \mathrm{~min}$, raised $5 \mathrm{~min}$, raised $5^{\circ} \mathrm{C} / \mathrm{min}$ to $200^{\circ} \mathrm{C}$.

\section{Research Materials}

Certain vinegar products are circulating in Mecca and with one of the vinegar products circulating for people in Surabaya.

\section{Reagents}

Aqua demineralisata, ethanol 99,9\% p.a., isopropanol p.a. (Merck), dichloromethane p.a. (Merck), ethyl acetate p.a. (Merck), acetic acid p.a. (Merck).

\section{Research Design}

The vinegar products used in this study are certain vinegars that circulate in Mecca and vinegar circulating in Surabaya. Each time the analysis is replicated five times. The vinegar sample was extracted with the selected solvent to draw ethanol from the sample. Extras of ethanol in the selected solvent are injected into gas chromatography with the adjusted conditions and then calculating the ethanol content, expressed in volume/volume proxies (\%v/v). The results obtained are expressed in the profile between ethanol content in some vinegar samples.

\section{Optimization of Extracting Solvents}

To extract or extract alcohol from the sample matrix, try some organic solvents that do not mix with water and the polarity does not vary much with ethanol. The tried solvents were ethyl acetate, and dichloromethane.

The method is a dipipet of $3,0 \mathrm{~mL}$ sample inserted a test tube. Extracted five times, each time with $3,0 \mathrm{~mL}$ of selected solvent. The attempted solvent phase is collected in a $25,0 \mathrm{~mL}$ measuring flask. Adopted with $0,2 \%$ ethanol standard solution and add $0,2 \%$ isopropanol internal standard and shake until homogeneous. A total of $1,0 \mu \mathrm{l}$ is injected into gas chromatography. Observing results of chromatogram. The preferred solvent is a solvent which does not provide a peak coincident with the peaks of ethanol and isopropanol, separate from the impurity component and there is no residual content (impurities) of ethanol.

\footnotetext{
${ }^{\circ}$ Copyright by Pusat Riset dan Pengembangan Produk Halal Universitas Airlangga | e-ISSN: 2654-9778
} 


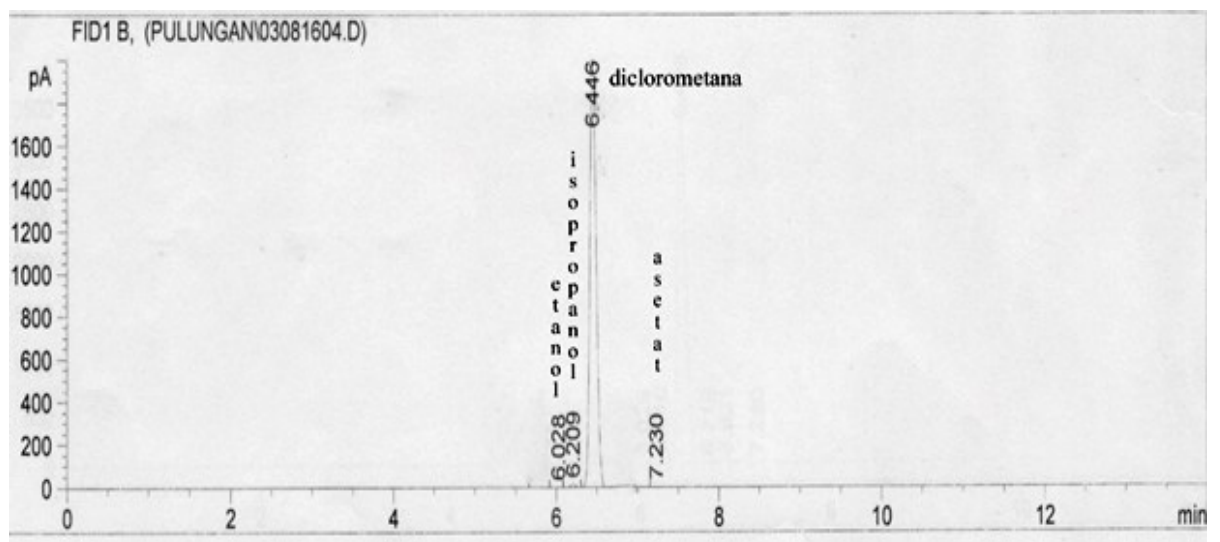

Figure 1 Profile of Dichloromethane chromatogram p.a injection volume 1,0 $\mu$ l with chromatographic tool at optimum condition indicates maturation time 6,446 minutes.

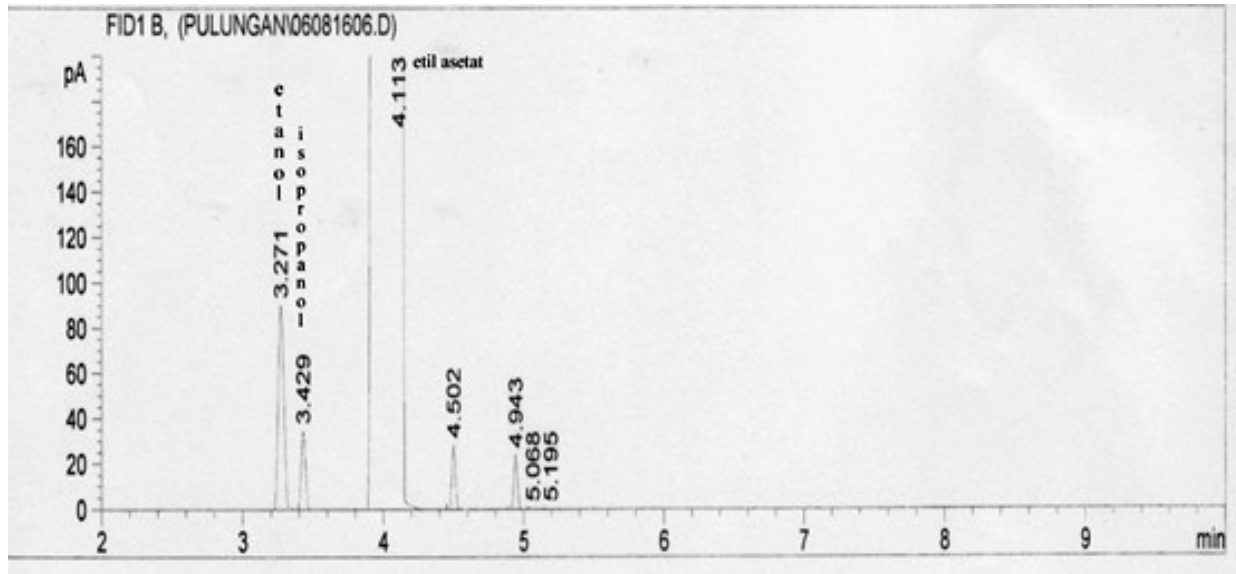

Figure 2 Profile of Ethyl acetate chromatogram p.a injection volume 1,0 $\mu$ l with gas chromatography tool shows maturation time 4,113 minutes.

The results of chromatogram observation with two kinds of tried solvent with the characteristics the results can be seen in Table 1

Table 1. Results of optimization of selected extracted solvent

\begin{tabular}{|c|c|c|}
\hline Solvent & $t_{R}$ (minutes) & Characteristics of results \\
\hline $\begin{array}{l}\text { Ethyl } \\
\text { Acetate }\end{array}$ & 4,113 & $\begin{array}{l}\text { - Impurities are relatively large } \\
\text { - Does not provide a peak coherent } \\
\text { - Contains residual (impurities) at } t_{R}= \\
\text { 3,271 minutes }\end{array}$ \\
\hline $\begin{array}{l}\text { Dichloro- } \\
\text { methane }\end{array}$ & 6,446 & $\begin{array}{l}\text { - Has no impurities } \\
\text { - Does not provide peaks that are } \\
\text { coinciding with } \\
\text { - Point contains residues (impurities) }\end{array}$ \\
\hline
\end{tabular}

\section{RESULT AND DISCUSSION}

\section{Qualitative Test of Ethanol in Vinegar}

The qualitative test of ethanol content in vinegar was done by 2 methods, ie comparative ethanol retention time to sample and qualitative test with addition method. To compute the pure ethanol retention time to the sample, two chromatograms derived from pure ethanol injection and the results of prepared

\footnotetext{
${ }^{\circ}$ Copyright by Pusat Riset dan Pengembangan Produk Halal Universitas Airlangga | e-ISSN: 2654-9778
} 
vinegar sample. From two chromatograms that produced are compared to the time retention of pure ethanol and ethanol components in vinegar. Figure 3.a and 3.b respectively shows the pure ethanol chromatogram and ethanol present in the sample by using an Agilent 6890 gas chromatograph with a FID detector. It has been shown that the pure ethanol retention time of 6,040 minutes has similarity to the peak of the chromatogram in vinegar sample. This suggests that in the vinegar preparation contained a compound which has a similar time retention with pure ethanol. Therefore, suspected vinegar samples contain ethanol
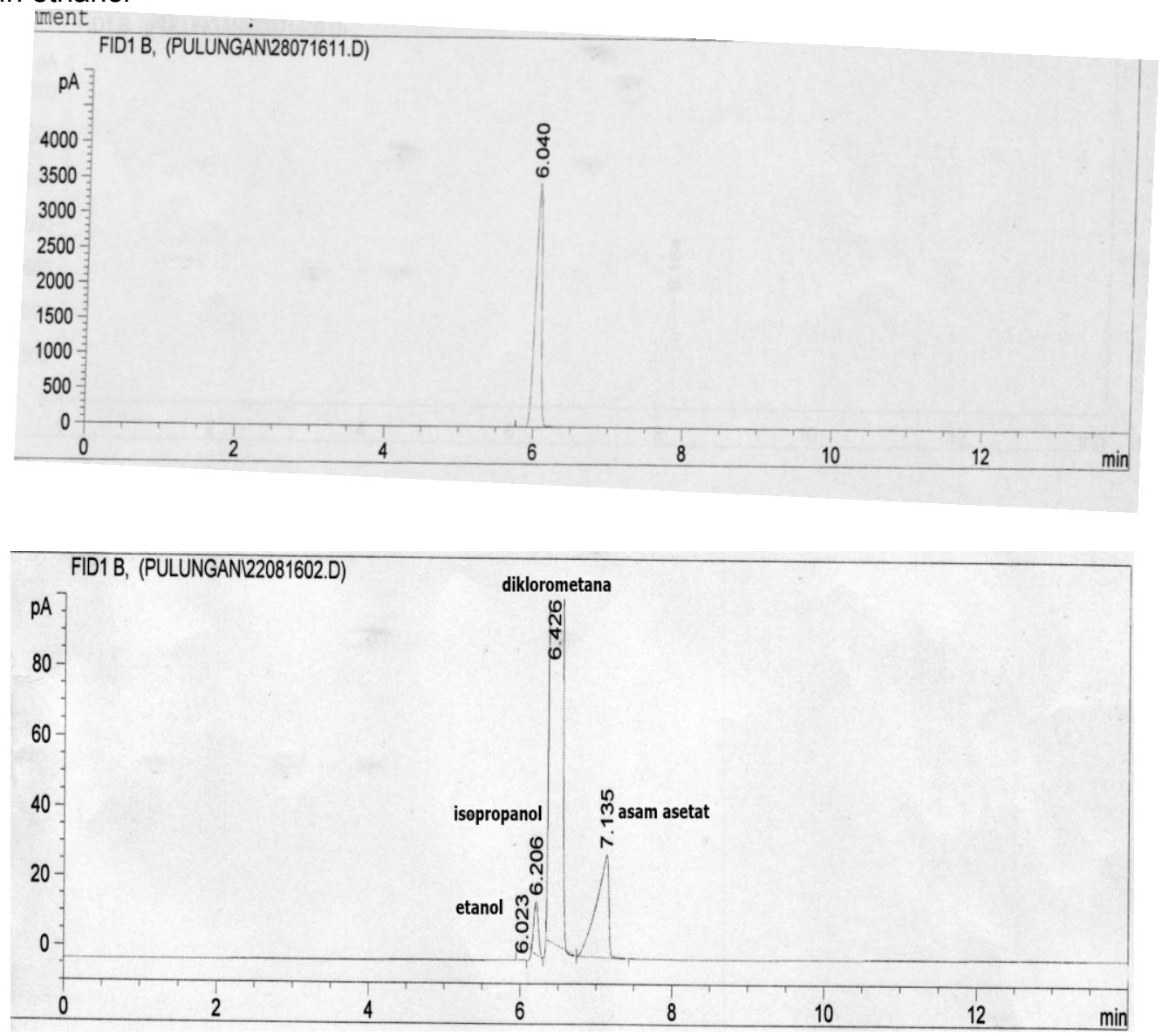

Figure 3 Chromatogram of pure ethanol (a) and the prepared vinegar acetic acid sample (b), using gas chromatography.

\section{Qualitative Test by Addition Method}

To strengthen the qualitative test results with retention time, an addition method is performed. The result of vinegar sample preparation was added pure ethanol with content $0,1998 \%$. Figure $4 a$ shows the peak of the sample chromatogram which not being added with ethanol, whereas in figure 4.b it appears that the addition of pure ethanol will increase the chromatogram peak at 6,023 minutes. This suggests that the addition of pure ethanol will increase the levels in the vinegar preparations thus increasing the chromatogram area, while on the left or right of the 6,023 mooring time there is no new peak. These results indicate that there is a compound component of the vinegar preparation having the same structure with the added compound, it is ethanol. By using two qualitative tests above, it can be concluded that in the prepared vinegar preparations contained ethanol compounds that appeared at the time of mooring around 6,023 minutes using Agilent gas chromatography 6890.

\footnotetext{
${ }^{\circ}$ Copyright by Pusat Riset dan Pengembangan Produk Halal Universitas Airlangga | e-ISSN: 2654-9778
} 


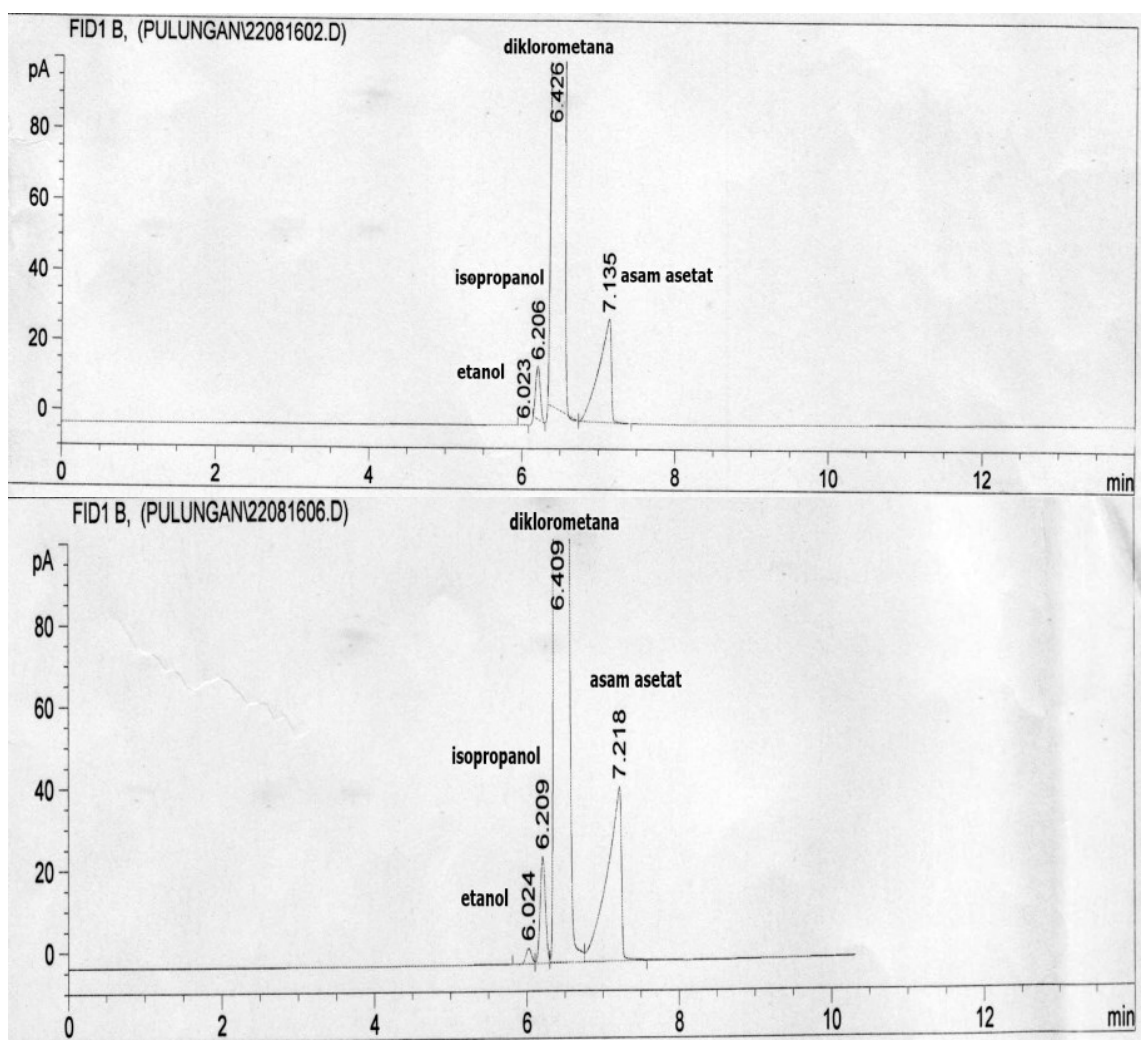

Figure 4 Chromatogram which produced by gas chromatography. (a) The ethanol peak in the mooring time of 6,023 minutes from vinegar sample. (b) The ethanol peak in the mooring time of 6,023 minutes from vinegar samples after the addition of pure ethanol

\section{Validation Method}

\section{Selectivity Test}

The selectivity test was performed to determine the separation between two compared analytical peaks, by injecting a mixture of ethanol, isopropanol, dichloromethane, and acetic acid in the same ratio. Chromatogram of selectivity test results can be seen in figure 5 . From the measurement results obtained the degree of separation as table 2

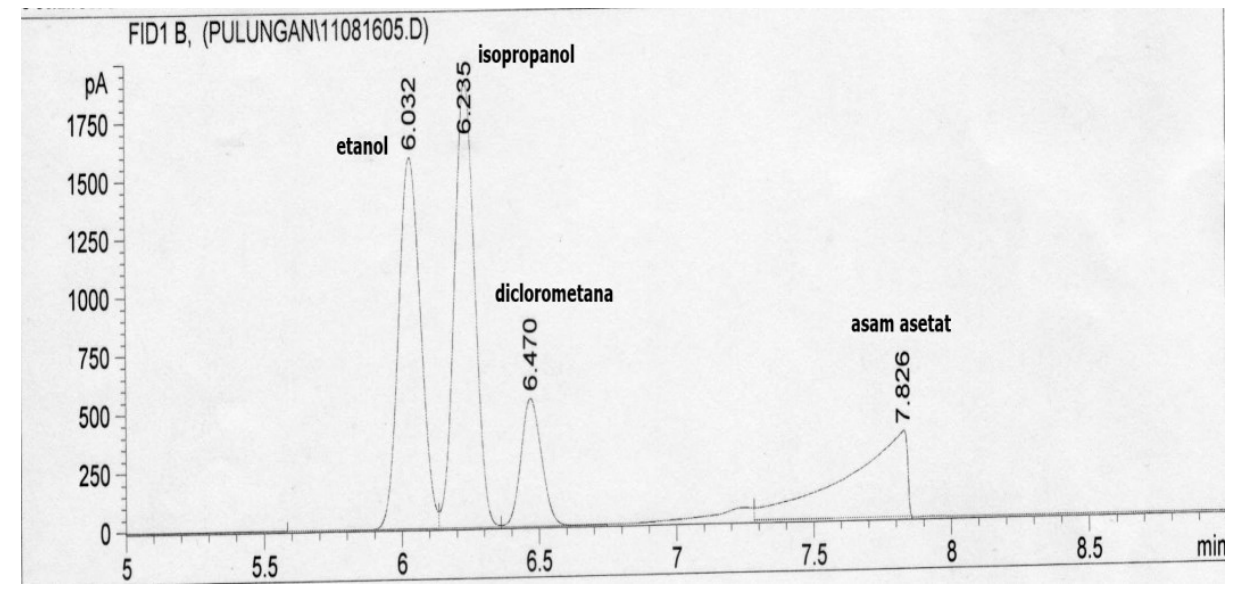

Figure 5. Chromatogram of $1,0 \mu \mathrm{l}$ injection volume selectivity test results by gas chromatography tool at optimum condition.

\footnotetext{
${ }^{\circ}$ Copyright by Pusat Riset dan Pengembangan Produk Halal Universitas Airlangga | e-ISSN: 2654-9778
} 
Table 2 The result of calculating the price of the resolution of some analyte from chromatogram in figure 3

\begin{tabular}{|l|l|}
\hline \multicolumn{1}{|c|}{ Mixed Analit } & Rs \\
\hline ethanol-isopropanol & 2,5439 \\
\hline ethanol-dichloromethane & 5,4041 \\
\hline isopropanol-dichloromaethane & 2,9841 \\
\hline acetic acid-ethanol & 12,2835 \\
\hline acetic acid-ispropanol & 11,0678 \\
\hline acetic acid-dichloromethane & 9,3517 \\
\hline
\end{tabular}

The result of selectivity test of all components shows that selectivity fulfill the method validation requirement that is (Rs) $>1,5$ (Skoog, 2007). This indicates that the method is selective, being able to separate the ethanol components and other components in the sample.

\section{Linearity Test}

Observations have been made by using gas chromatography to obtain the relationship between 7 ethanol content levels and comparison of standard area with internal standard as in table 3 . After that calculation, then obtained regression equation $y=4.50633 x-0.01325$ and correlation coefficient $r=$ 0,9995 , while the price $r$ table $(\alpha=1 \%, n=6)=0,834$, so $r$ count $>r$ table. Another linearity parameter is Vxo (Terms $V x o<5 \%$ ) of linearity test results obtained $V x o$ results $3,88 \%$. Thus, it's getting a linear relationship between ethanol concentration and area. The obtained standard curve from the determination of the linearity can be seen in figure 6 . The $\mathrm{x}$-axis represents the ethanol content $(\% \mathrm{v} / \mathrm{v})$ and the $y$-axis represents the ratio of the ethanol and ispropanol (Ae/Aiso) areas.

Table 3 Determination of linearity of alcohol determination in the preparation of fermented vinegar by gas chromatography

\begin{tabular}{|c|c|c|}
\hline No. & $\begin{array}{c}\text { Ethanol Content } \\
(\% \mathrm{v} / \mathrm{v})\end{array}$ & (Ae/Aiso) \\
\hline 1 & $0,024975 \%$ & 0,12600 \\
\hline 2 & $0,049950 \%$ & 0,24153 \\
\hline 3 & $0,099900 \%$ & 0,40318 \\
\hline 4 & $0,199800 \%$ & 0,86981 \\
\hline 5 & $0,499500 \%$ & 2,15263 \\
\hline 6 & $0,999000 \%$ & 4,63324 \\
\hline 7 & $1,498500 \%$ & 6,67451 \\
\hline
\end{tabular}

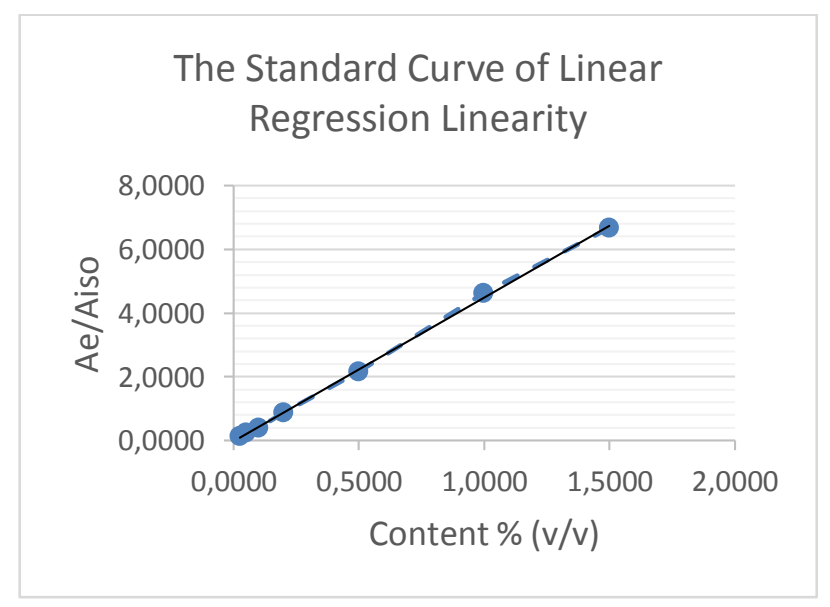

Figure 6 The standard curve of the linearity regression relationship between the ratio of the ethanol area and the isopropanol area to the ethanol content.

\footnotetext{
${ }^{\circ}$ Copyright by Pusat Riset dan Pengembangan Produk Halal Universitas Airlangga | e-ISSN: 2654-9778
} 
Preparation of standard curve was made by connecting seven kinds of standard alcohol content which has added isopropanol as internal standard and measured the comparative price of standard alcohol area with internal standard so obtained a linear correlation between alcohol content with comparison of obtained area expressed by equation of regression line. The existence of linear relationship is indicated from the price of $r$ count greater than $r$ table so it can be concluded that there is a linear correlation between alcohol content with ratio of alcohol area and internal standard so that slope generated from standard curve equation can be used as factor to calculate alcohol content in sample

\section{Precision}

To determine the precision, it's done by preparation six times with the same treatment as sample preparation and then injected into gas chromatography and calculated standard deviation (SD) and \% coefficient of variation (\%KV), on the determination of this method precision obtained SD $=6,36.10^{-4}$ and $\mathrm{KV}=5,34 \%$ which means fulfilling the precision requirements of bioanalysis ( $\mathrm{KV}<10 \%$ ) (Yuwono and Indrayanto, 2005). The result of observing chromatogram area is listed in table 4. This shows the precision of etano-determination method in vinegar samples by using sufficient gas chromatography is accurate.

\section{Test Accuracy}

Accuracy test is done by adding standard ethanol to the sample and processed in the same way as the sample preparation method. The obtained data can be seen in Table 5

Table 4 Precision determination for determination of ethanol content in fermented vinegar preparations by gas chromatography method.

\begin{tabular}{|c|c|}
\hline Replication & Ae Aiso(X) \\
\hline 1 & 0,011504 \\
\hline 2 & 0,012734 \\
\hline 3 & 0,011385 \\
\hline 4 & 0,011318 \\
\hline 5 & 0,012650 \\
\hline 6 & 0,011829 \\
\hline \multicolumn{2}{|c|}{$X=0,011903 ;$ SD $=6,36.10^{-4} ;$} \\
KV $=5,34 \%$ \\
\hline
\end{tabular}

Table 5 Determination of accuracy for determination of ethanol content in fermented vinegar preparations by gas chromatography method.

\begin{tabular}{|c|c|c|}
\hline No. & addition reaction of ethanol (\%) & \% average recovery \\
\hline 1. & 0,1996 & 103,21 \\
\hline 2. & 0,4995 & 100,02 \\
\hline 3. & 0,9990 & 100,53 \\
\hline \multicolumn{2}{|c|}{$\mathbf{A}=\mathbf{1 0 1 , 2 5}$} \\
$\mathbf{K v}=\mathbf{5 , 6 3} \%$ \\
\hline
\end{tabular}

On the determination of accuracy obtained $\%$ average recovery $101,25 \%$ with $\mathrm{KV}=5,63 \%$. The $\%$ accuracy requirement for the addition $\geq 1 \%$ is $80-110 \%, \mathrm{KV}$ is $7,3 \%$ (Yuwono and Indrayanto, 2005). So it can be concluded that the measurement accuracy meets the requirements.

\section{Detection Limit (LOD) and Quantitation Limit (LOQ)}

LOD and LOQ tests were performed to determine the sensitivity of the tools used in the analyte is ethanol. The calculation of the detection limit value (LOD) and the quantitatiom limit (LOQ) of the five different ethanol concentrations are different. The calculation result from LOD LOQ standard curve can be seen in table 6 , table 7 and figure 7

\footnotetext{
${ }^{0}$ Copyright by Pusat Riset dan Pengembangan Produk Halal Universitas Airlangga | e-ISSN: 2654-9778
} 
Table 6 Determination of linearity slope measurement of LOD and LOQ of ethanol

\begin{tabular}{|c|c|c|}
\hline No. & Grade (\%v/v) & (Ae/Aiso) \\
\hline 1 & 0,02497 & 0,12600 \\
\hline 2 & 0,04995 & 0,24153 \\
\hline 3 & 0,09990 & 0,40318 \\
\hline 4 & 0,19980 & 1,00116 \\
\hline 5 & 0,49950 & 2,15263 \\
\hline
\end{tabular}

Table 7 LOD and LOQ Determination

\begin{tabular}{|c|c|c|c|c|}
\hline No. & Grade (X) & Ae/Ai (Y) & $\widehat{\boldsymbol{y}}$ & $\left(\boldsymbol{Y}-\widehat{\boldsymbol{y}}^{\mathbf{2}}\right.$ \\
\hline 1 & 0,02497 & 0,12600 & 0,11660 & $8,84.10^{-5}$ \\
\hline 2 & 0,04995 & 0,24153 & 0,22360 & $3,21.10^{-4}$ \\
\hline 3 & 0,09990 & 0,40318 & 0,43761 & $1,18.10^{-3}$ \\
\hline 4 & 0,19980 & 0,86981 & 0,86562 & $1,75.10^{-5}$ \\
\hline 5 & 0,49950 & 2,15262 & 2,14966 & $8,81.10^{-6}$ \\
\hline & 0.174825 & & & $1,62.10^{-3}$ \\
\hline
\end{tabular}

\section{Curve of}

LOD LOQ

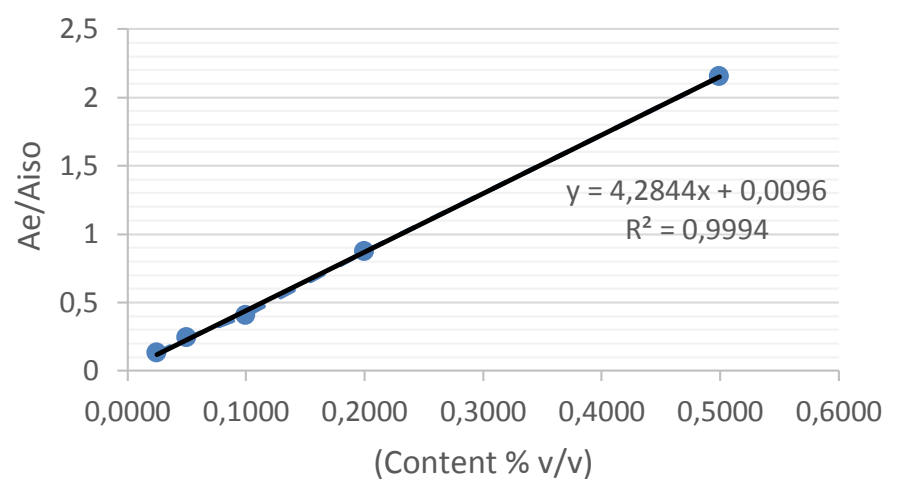

Figure 7 LOD and LOQ raw curve relationship between ethanol area ratio and isopropanol area to ethanol content.

From the calculation results obtained LOD price is $4,89.10^{-4} \%$ and LOQ price is $1,48.10^{-3} \%$ with the regression curve equation LOD and LOQ curve is $y=4,2844 x-0.0096$ and the value of coefficient of variation $(r)$ is 0,9997 . These suggest that the lowest ethanol content which is detected by the gas chromatographic tool is $4,89.10^{-4} \%$ and the lowest quantitatively measured ethanol content is $1,48.10^{-3}$ $\%$.

Based on the validation test which includes selectivity test, linearity, accuracy, tool precision, precision method, LOD and LOQ, the gas chromatography method has fulfilled the validation requirement so that this method is valid for determination of ethanol content in vinegar sample preparation.

\section{Determination of Ethanol Content in Sample of Vinegar Preparations.}

The next stage is to determine the level of ethanol in vinegar preparations. Each sample is arabic vinegar and vinegar in the market. They are replicated three times for each sample. The vinegar samples were extracted five times by using dichloromethane to draw ethanol from water. Then it is centrifuged so that both of phases can be clearly visible and easier to separate. The accumulated dichloromethane

\footnotetext{
${ }^{\circ}$ Copyright by Pusat Riset dan Pengembangan Produk Halal Universitas Airlangga | e-ISSN: 2654-9778
} 
phase plus $0,2 \%$ isopropanol standard internal. Then injected as much as $1,0 \mu \mathrm{l}$ of solution into gas chromatography.

From the chromatogram profile obtained ethanol and isopropanol area data. The results of determining the ethanol content in each vinegar sample can be seen in the respective tables 8 to 9 .

Table 8 Determination of ethanol content in vinegar preparations (originating from Saudi Arabia) by gas chromatography method.

\begin{tabular}{|l|c|c|c|c|c|}
\hline \multirow{2}{*}{ Sample } & Ae/Aist & $\begin{array}{c}\text { Ethanol Content } \\
(\% \mathbf{\%} / \mathbf{v})\end{array}$ & $\begin{array}{c}\text { Convertion } \\
\text { of content to \% } \\
\text { recovery }(\% \mathbf{\%} / \mathbf{v})\end{array}$ & $\begin{array}{c}\text { Average ethanol } \\
\text { content (\%v/v) }\end{array}$ \\
\hline \multirow{2}{*}{$\begin{array}{l}\text { Arabic } \\
\text { vinegar }\end{array}$} & 0,01046 & $5,05.10^{-2}$ & $4,89.10^{-2}$ & \multirow{2}{*}{$2,28.10^{-2}$} \\
\cline { 2 - 4 } & & 0,01582 & $1,07.10^{-2}$ & $1,04.10^{-2}$ & \\
\hline
\end{tabular}

Table 9 Determination of ethanol content in vinegar preparations (circulating freely in the market) by gas chromatography method.

\begin{tabular}{|c|c|c|c|c|}
\hline Sample & Ae/Aiso & $\begin{array}{c}\text { Ethanol content } \\
(\% \mathbf{\%} / \mathbf{v})\end{array}$ & $\begin{array}{c}\text { Convertion } \\
\text { of content to \% } \\
\text { recovery }(\% \mathrm{v} / \mathbf{v})\end{array}$ & $\begin{array}{c}\text { Average ethanol } \\
\text { content (\%v/v) }\end{array}$ \\
\hline $\begin{array}{c}\text { Vinegar in } \\
\text { the market }\end{array}$ & 0,92556 & $8,53.10^{-3}$ & $8,26.10^{-3}$ & \multirow{2}{*}{$1,17.10^{-2}$} \\
\cline { 2 - 4 } & 0,96580 & $1,75.10^{-2}$ & $1,69.10^{-2}$ & \\
\hline
\end{tabular}

From the calculation results obtained the average level of ethanol from Arabic vinegar is $2,28.10^{-2} \% \mathrm{v} / \mathrm{v}$, and on vinegar ' $x$ ' in the market is $1,17.10^{-2} \% \mathrm{v} / \mathrm{v}$.

\section{CONCLUSION}

From the results of research can be concluded that:

1. Gas-DIN chromatographic methods meet the requirements of validation parameters (Selectivity, linearity, accuracy, precision, LOD and LOQ) for qualitative and quantitative analysis of ethanol content in vinegar preparations.

2. In the quantitative analysis, the determination of ethanol content of vinegar preparations derived from Saudi Arabia is $2,28.10^{-2} \% \mathrm{v} / \mathrm{v}$, and on the vinegar ' $\mathrm{x}$ ' in the market is $1,17.10^{-2} \% \mathrm{v} / \mathrm{v}$.

\section{REFERENCE}

Anonim. 2014. Farmakope Indonesia Edisi V. Jakarta : Departemen Kesehatan Republik Indonesia, hal. $399-401 ; 1686$.

Badan Standarisasi Nasional. 1996. Cuka Fermentasi. SNI 01-4371-1996. Departemen Perindustrian Republik Indonesia Jakarta.

Departemen Kesehatan Republik Indonesia. 2008. Peraturan Menteri Kesehatan Republik Indonesia Nomor 86/Men.Kes/Per/IV/77 tentang Minuman Keras. Jakarta: Menteri Kesehatan Republik Indonesia, hal. 1-7

Departemen Perdagangan Republik Indonesia, 2014. Peraturan Menteri Perdagangan R.I. Nomor 20/MDAG/PER/4/2014 tentang Pengendalian dan Pengawasan Terhadap Pengadaan, Peredaran, dan Penjualan Minuman Beralkohol. Jakarta: Direktur Impor Kementrian Perdagangan, hal. 5

Gilman AG, Goodman LS, Brunton LL, Chabner B, Knollmann BC. 2011. The Pharmacological Basis of Therapeutic, $12^{\text {th }}$ Ed. New York: McGraw-Hill Medical

Hosen I. 1993. Status Hukum Alkohol. Dalam Hasil Muzakarah Nasional: Alkohol dalam Produk Minuman. Jakarta : Majelis Ulama Indonesia

Ibrahim SY, Hassaballah AA., 2011. Petroleum science and technology production of acetic acid by oxidation of butane with air under high pressure. Journal of Petroleum Science and Technology 23(1): 37-41.

\footnotetext{
${ }^{\circ}$ Copyright by Pusat Riset dan Pengembangan Produk Halal Universitas Airlangga | e-ISSN: 2654-9778
} 
Johnston CS, Gaas CA. 2006. Vinegar: medicinal uses and antiglycemic effect. Medscape General Medicine, 8(2): 61.

Latimer GW. 2012. Official Methods of Analysis. Washington DC: Association of Offical Analytical Chemist Inc $19^{\text {th }}$ Edition, pp. 952.08A..

Skoog DA, Holler FJ, Timothy AN. 2007. Principles of Instrumental Analysis. $5^{\text {th }}$ Ed. Florida: Harcount Brace \& Company, pp. 674-722.

Sun H, Wang A. 2012. Application of accelerated solvent extraction in the analysis of organic contaminants, bioactive and nutritional compounds in food and feed. Journal of Chromatogam Application, 1237: 1-23. Doi: https://doi.org/10.1016/j.chroma.2012.03.003

Tan SC. 2005. Vinegar Fermentation. Louisiana State Univ: Baton Rouge. p 101s.

Tjahjono AE, Dyah P, Hartono M., 2007. Kondisi optimum fermentasi asam asetat menggunakan acetobacter aceti B166. Jurnal Sains MIPA Unila 13 (1): 17-20.

Yuwono M, Indrayanto G. 2005. Validation of chromatographic method analysis. Profiles of Drug Substance, Excipients, and Related Methodology, 32: 243-259. Doi: https://doi.org/10.1016/S00995428(05)32009-0

${ }^{\circ}$ Copyright by Pusat Riset dan Pengembangan Produk Halal Universitas Airlangga | e-ISSN: 2654-9778 